\title{
The effectiveness of Government Policies for Export Promotion on the Export Performance of SMEs Cocoa Exporters in Cameroon
}

\begin{abstract}
Purpose - This research examines the significance of the direct and indirect effects (through country and firm's specific advantages) of government policies for export promotion (GPEP) on the export performance of SME Cocoa exporters in Cameroon.
\end{abstract}

Design/methodology/approach - To test the proposed model, was data obtained through selfadministered questionnaires using snowball sampling technique to 101 SME Cocoa exporters. This was analysed using structural equation modelling techniques to examine both the direct and indirect effects of GPEP on the export performance of SME Cocoa exporters in the South and Centre Regions of Cameroon.

Findings - The findings suggest that GPEP had both direct and indirect effects on the export performance of SME Cocoa exporters. Direct effect was on the usage of GPEP which reduces operating cost and increase performance. The indirect effects were through the provision of country and firms specific advantages. However, the only significant path was through the provision of export marketing information.

Research limitations/Implications - The research is limited to one country, one sector, and two regions and does not take into consideration other factors that may influence the effect of GPEP, country, and firms specific advantages on export performance. Moreover, the non-significant paths should be interpreted with caution and further testing required in a different context.

Practical implications - Empirical findings are relevant for the government and SME Cocoa exporters. It informs the government about the effectiveness of GPEP and the need to disseminate marketing information using every possible medium best understood by the SMEs. It suggests an opportunity for engagement of both SMEs and government authorities in accessing the outcome of GPEP which will increase transparency, awareness, usage and export performance. 
Originality/Value - The research has successfully developed and tested a model for analysing the direct and indirect effects of GPEP on export performance based on the RBV and SEM in a context where there is a call for more empirical and theoretical work on export performance due to limited studies. The framework reveals positive effects of GPEP, country, and firms' specific advantages as determinants of export performance.

Keywords: Export promotion programs, Export performance, SME Cocoa exporters, Country specific advantages, Firms specific advantages, Cameroon

\section{Introduction}

Exporting is becoming the most common form of internationalization because it is associated with minimal resources, lower risk and structural flexibility (Olejnik and Swoboda, 2012). This has made it possible for Small and Medium-size Enterprise (SMEs) to increasingly become involved in global trade. The case of SME Cocoa exporters in Cameroon is no difference. However, the extent of their internationalization is limited by the barriers to exporting (Leonidou, 1995; Leonidou et al., 2011). Exporting has both macro and micro benefits to the economy. These economic benefits form the basis for government intervention in encouraging exporting (Francis and Collins-Dodd, 2004; Gençtürk and Kotabe, 2001). This intervention takes the form of policy provisions to provide both financial and non financial resources (Leonidou, 2004). These resources also helps SMEs overcome barriers to internationalise and motivates both exporters and non-exporters to pursue exporting (Leonidou, 2004; Gençtürk and Kotabe, 2001). This form of government policy intervention to improve exporting and export performance is called export promotion programs (Francis and Collins-Dodd, 2004; Gençtürk and Kotabe, 2001). The OECD broadly defines GPEP as the set of 'specific measures that amount to the government bearing a portion of the private cost of production of exporting' (OECD, 1984).

SME Cocoa exporters in Cameroon constitute an ideal research context to investigate the role of GPEP on export performance for two reasons. The first is related to the evolution of international Cocoa marketing from a predominantly state-owned/controlled monopoly before the late 1980s and the increasing privatisation after that which saw the growth of SMEs Cocoa exporters (Coulter and Abena, 
2010). This evolution and the growing number of SME Cocoa exporters creates a research need to investigate the effectiveness of GPEP on the export performance of SME Cocoa exporters in Cameroon. Given that this is an under-researched area, the findings improve our understanding not only of the effects of GPEP, but also the practical and policy implications for helping SME Cocoa exporters to maximise the benefits of GPEP.

Secondly, studies on Africa, therefore, are important because they reveal a dearth of international involvement by African firms which makes advancing theory in Africa a paramount issue to export development (Darlene, 2015; Jieke et al., 2016). Africa is responsible for more than $75 \%$ of Cocoa produce and exported globally which makes it a global phenomenon worth investigating (Boansi 3013; ICCO, 2014). Regarding Cocoa exporting, Cameroon is ranked $4^{\text {th }}$ in Africa and $5^{\text {th }}$ in the world (ICCO, 2014). The Cocoa sector is a priority area for the Cameroonian government, employing about $70 \%$ of the rural population and contributing $14 \%$ to total export earnings (ICCO, 2014) in spite of price volatility (IMF, 2015). Cameroon's major export destinations are; Spain 13.3\%, Netherland 9.7\%, China $11.4 \%$, Italy $6.8 \%$, France $6.4 \%$ and USA 5.9\%, Germany 4.8\%, Belgium 4\% ( IMF country stat. 2014).

A review of the literature shows that studies on export performance have focused on many types of determinants (Harif et al., 2013). These determinants have also influenced export performance both positively and negatively based on the performance measures and method of analysis used (Jieke et al., 2016). This research considers GPEP as an external determinat of export performance that influences export performance directly and indirectly through other variables (Gençtürk and Kotabe, 2001; Francis and Collins-Dodd, 2004). GPEP is available for every firm to access (Sraha, 2015; Leonidou et al., 2011).

According to Jieke et al., (2016), the dominant theoretical underpinning and method of analysis of export performance model have been the resource based view (RBV) and structural equation modelling (SEM) techniques. These studies have, however, reported mixed results (Jieke et al., 2016). Moreover, literature on the effectiveness (direct, indirect or direct and indirect effects) of GPEP and export performance have revealed mixed results. According to Gençtürk and Kotabe (2001), GPEP had a non-significant relationship with profitability and export share but a positive correlation with the competitive 
positioning of the firm. Moreover, Francis and Collins-Dodd (2004) reported that the direct effect was not significant based on the fact that some businesses were benefiting from fewer programs. Lages and Montgomery (2005) also reported mixed findings with the direct effect of export promotion programs on export performance positively significant and the indirect effect highly insignificant. Also, Sraha (2015) reported a positive relationship based on the fact that GPEP helps firms develop their international marketing strategy. $\mathrm{Ng}$ et al., (2016) reveal that GPEP improves product quality and potentially increasing sales revenue. However, Geldres-Weiss and Carrasco-Roa (2016) did not find any significant relationship between performance among firms benefiting or not benefiting from GPEP. Geldres-Weiss and Carrasco-Roa (2016) question whether there is a need for GPEP as firms have achieved improved export performance without benefiting from such policies.

Furthermore, most of the prominent studies on the effectiveness of GPEP on export performance have been based on the developed world (Leonidou et al., 2011; Shamsuddoha et al., 2009; Francis and Collins-Dodd, 2004; Jindal and Gakhar, 2015; Geldres-Weiss and Carrasco-Roa, 2016). The lack of prominent studies in developing economies like Cameroon has been echoed by Sraha (2015) and Sousa et al. (2008) who called for the advancement of theory in the domestic environment. This call is further strengthened by Jieke et al., (2016) who did a review of export performance literature and reported very limited studies on the export performance models that have focused on African countries. This research responds to the call to develop a model for export performance in the domestic market domain in Cameroon. Moreover, despite the many types of research on the determinants of export performance, Zhang (2016) have reported a lack of empirical research on how locational advantages can influence export performance. In the Cameroon, Ngoasong (2007) reveals that SMEs in Cameroon do not have any clear strategy. Coupled with limited resources, GPEP, is conceptualized in this research to provide country and firm-specific advantages that are considered as a starting point for building capabilities for successful exporting and therefore responding to the call of Zhang (2016) for more empirical work on country advantages as determinants of export performance.

To contribute to filling the above research gap, two important research questions are explored in this research; 1) Given the growing involvement of local SMEs in the export of Cocoa in African countries 
and Cameroon in particular, how can the role of GPEP on the export performance of SME Cocoa exporters be best understood? 2) What are the direct and indirect effects of government policies for export promotion on the export performance of SME Cocoa exporters in Cameroon? To answer these questions, this research develops and empirically tests a conceptual framework based on RBV to explores the direct and indirect effects of GPEP on the export performance of SME Cocoa exporters in Cameroon. Directly through policies targeted to improve export performance and indirectly through country advantages, export finance, export marketing and management capabilities. To achieve the research objective, this research uses Structural Equation Modelling (SEM) technique. It starts with the application of exploratory factor analysis (EFA) as a purification mechanism to minimize the data and uncover underlying factors. The next stage deals with the applicability of confirmatory factor analysis (CFA) to test and improve model fit indices. The last stage involves path diagram on the analysis of moment structures (AMOS) software to determine direct and indirect effects with their level of significance.

By answering the research questions, this research contributes to the recent debate in international marketing in a sector (Cocoa sector) that is unique in natural resource-rich developing countries such as Cameroon. This uniqueness also stems from the evolution of Cocoa exporting in Cameroon. Before the 1960s, Cocoa exporting in Cameroon was monopolised by the government under the defunct marketing board. However, economic liberalisation in the 1990s saw the growth of SME Cocoa exporters (SMEs involved in the buying and selling of Cocoa directly or indirectly) (Coulter and Abena, 2010). Answering the above questions will help SME Cocoa exporters understand the effectiveness of GPEP and how they can benefit more to improve their performances. It will also inform the government of ways in which the effectiveness of GPEP on export performance can be enhanced.

Secondly, this research contributes to the theoretical literature on international export marketing (e.g., Francis and Collins-Dodd, 2004). The contribution is by exploring the RBV and SEM techniques to develop and empirically test a model of export performance. This model depicts nine propositions and thereby uncovers the direct and indirect effects (through country and firms specific advantages) of GPEP on the export performance of SME Cocoa exporters in Cameroon. There has been much representation 
of GPEP in the developed world (Jieke et al., 2016) with little in developing economies such as those in Africa and especially Cameroon where such research is non-existent. The empirical model explored in this research can be applied to other under-researched contexts - beyond Cameroon (Jieke et al., 2016; Francis and Collins-Dodd, 2014; Ibeh et al., 2012; Tore, 2013). Even though country advantages have been conceptualized as determinants of export performance, empirical analysis has so far been very limited especially in Cameroon. This study responds to the call from Francis and Collins-Dodd (2004) to explore different country/context and different sectors.

This research is anchored within the context of the resource-based view (RBV) of the firm. The government is the largest provider of external resources to firms and GPEP is a perfect example of a bundle of resources that SMEs can benefit from to improve their performance. Through GPEP SMEs can obtain finance, marketing knowledge, and information, technology among others. These are resources that are scarce and valuable to SMEs to pursue exporting. The framework, therefore, consists of GPEP directly influencing export performance and indirectly through its effects on other determinants of export performance.

The next section presents the RBV as the theoretical framework for this study and develop specific hypotheses. This is followed by a description of the research method, presentation, and discussion of results, a conclusion followed by a discussion of the limitations and direction of future research.

\section{Literature Review and Development of Hypothesis}

\section{The Resource Base View of the firm}

The conceptual framework for this study draws on the RBV of the firm as a theoretical starting point. The RBV of the firm categorically emphasizes on the firm's resources and capabilities to build competitive advantages for the firm which improves performance (Mário et al., 2016). These resources and capabilities have been viewed as varied and as important determinants of export performance (Tan et al., 2015). Based on Leonedou et al., (2011); Francis and Collins-Dodd (2004), GPEP seems to be an important resource and external determinants of export performance as they help SMEs overcome barriers to exporting due to limited resources (Gençtürk and Kotabe, 2001). 
GEPE can enable SMEs to build capabilities for successful exporting through the provision of both country and firms specific advantages. Country specific advantages are locational factors that influence export performance by providing resources and making the business environment more attractive for investment (Freeman et al., 2012; Pinho, 2007; Rugman, 2010; Joanne and Chris, 2014). Moreover, the decision to export may be based on the support from the domestic market environment (Lages and Sousa, 2010). These domestic market advantages are categorized as country specific advantages in this research. (Zhang, 2016). It is also assumed that firms benefit from these country specific advantages to building a wealth of resource (financial, marketing and management capabilities) for successful exporting (Xiao et al., 2014; Chai et al., 2014). This, therefore, implies that GPEP can provide both country and firms specific advantages. GPEP provides locational advantages such as networking through policies such as trade shows and seminars (Xinming and Yingqi, 2013). Through GPEP, SMEs also benefit from finance for exporting, marketing and management capabilities through training and workshops. However, empirical research that discusses how country and firms specific advantages influence export performance is still limited. (Zhang, 2016).

GPEP ranges from workshops, seminars and how-to-export assistance, trade missions, trade and catalog shows, subsidies among others which act as an external resource to build capabilities for exporting and help overcome barriers to exporting and thereby increasing export performance (Gençtürk and Kotabe, 2001; Darlene, 2015). GPEP are important to SMEs because they do not benefit from large resources like large firms (Olejnik and Swoboda, 2012; Leonidou et al., 2011).

Penrose (1995) sees export performance as a measure of how well the firm achieves its goals (organizational and financial goals). However, there is no conceptually accepted definition of export performance which has led to the use of various dimensions of performance measurements (Lages and Sousa, 2010). These measurements can be categorized as either financial (subjective) or non-financial (objective) measure (Francis and Collins-Dodd, 2004). Financial measures are traditional performance measurements techniques and include measures such as profitability, return on investment, sales among others (Harif et al., 2013). On the other hand, also, non-financial measures are non-traditional performance measures that are based not on the balance sheet of the firm but on how the firm is 
performing among a spectrum of dimensions such as customer satisfactory, economies of scale among others (Harif et al., 3013). This study, therefore, combines both financial and non-financial performance measures to provide a balance performance measure.

Research on the effectiveness of GPEP on export performance have been limited and based on the direct effects, indirect effects or both (Shamsuddoha et al., 2009). According to Gençtürk and Kotabe (2001), GPEP had a non-significant relationship with profitability and export share but a positive relationship with the competitive positioning of the firm based on the level of export involvement. Moreover, Francis and Collins-Dodd (2004) reported that the direct effect was not significant and that performance is based on the number of programs used. Lages and Montgomery (2005) also reported mixed findings with the direct effect of export promotion programs on export performance positively significant and the indirect effect highly insignificant. Research by Ng et al., (2016) shows that GPEP leads to higher sales with profit. However, (Geldres-Weiss and Carrasco-Roa, 2016) compared a group of firms benefiting and not benefiting from GPEP and did not find any significant relationship with export performance. This mixed findings on the link between GPEP and export performance have raised the challenge for further analysis of the effectiveness of GPEP on export performance (Geldres-Weiss and Carrasco-Roa, 2016). This fragmentation of results has been largely due to among other factors the types of performance measures used (financial and non-financial), theoretical underpinning, direct or indirect (with different intervening variables), various measures of GPEP and above all different context and methods of analysis.

Based on the above review, it is GPEP is considered as an external resource that can help SMEs overcome the barriers of export. However, in an economy like that of Cameroon where SME lack a clear business strategy, the starting point is to develop capabilities and build competitive advantage. These competitive advantages can be achieved from GPEP and through country and firms specific advantages.

This is the basis upon which the conceptual framework below is built.

\section{Conceptual Framework and Hypotheses Development}

The Role of Government Policy for Export Promotion (GPEP) on SME Exporting 
This research develops a framework that based on the RBV that conceptualizes GPEP, country, and firms specific advantages as determinants of export performance. GPEP are pursued because of the benefits of exporting and the barriers to exporting faced by SMEs (Gencturk and Kotabe, 2001; Julian and Ali, 2009; Julian and Ahmed, 2005; Khazragui, 2011; Leonidou and Katsikeas, 1996). Based on the existing literature, the role of GPEP can be understood in two ways. The first is its effects on firmspecific advantages (export finance, export marketing, and management capabilities). The second is regarding country-specific advantages (GPEP aimed at creating an enabling environment for all firms within the industry and the economy as a whole) as shown in fig. 1. GPEP, in this case, include export assistance programs to help firms that have limited export experience, limited resources, real and perceived obstacles to exporting to achieve their export objectives.

Figure 1. Conceptual Framework

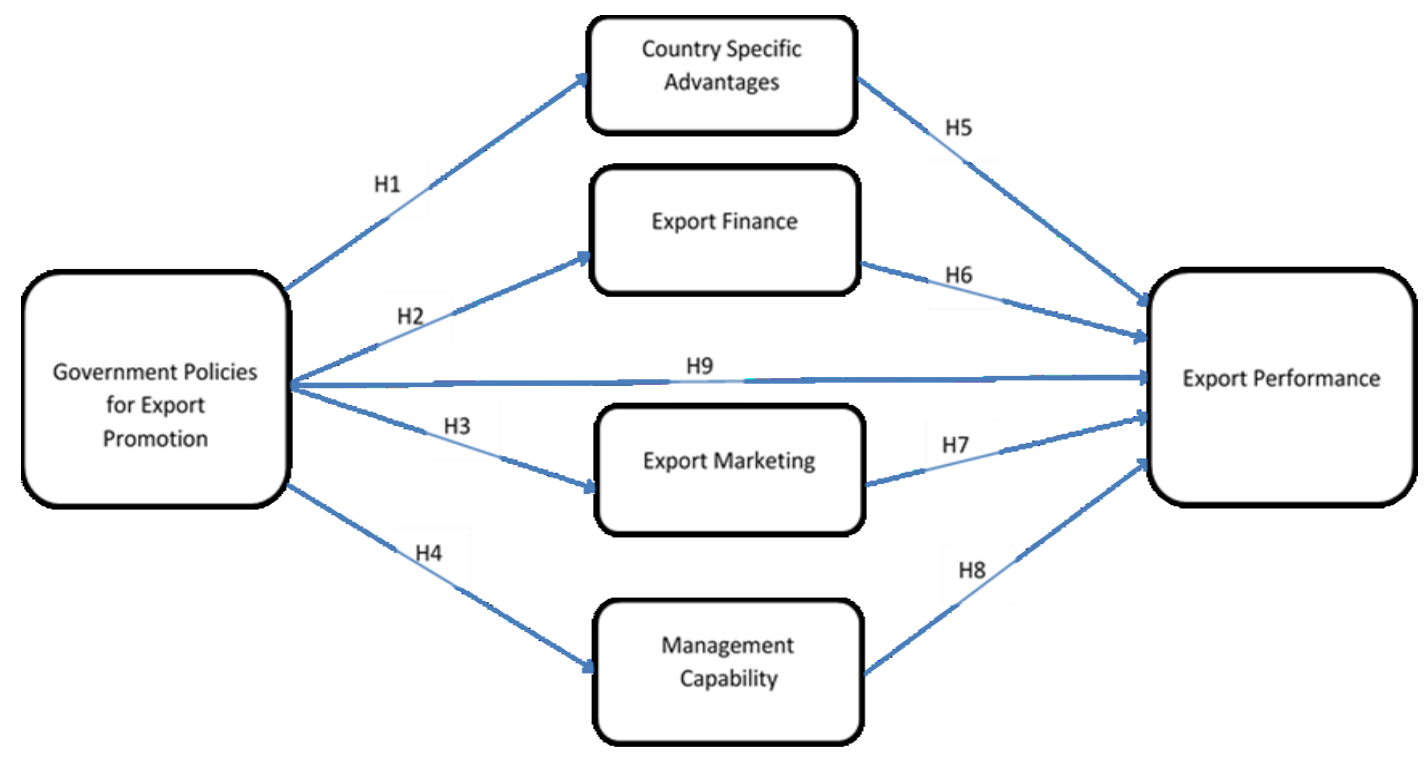

Source: Author's conceptualisation based the Literature Review

Location factors influence export performance through resource provisions (Freeman et al., 2012). It offers SMEs access to financial, non-financial resources and networking opportunities. Country specific advantages (CSA) act as potential drivers for internationalization (Pinho, 2007). However, CSAs originates from economic actions of the government (Zhang, 2016). This is because the government is the largest providers of external resource (Gencturk and Kotabe, 2001). CSAs have been used in this research to include networking facilities, provision of financial intermediaries, subsidies and laws that 
facilitate business creations. These advantages are the starting point of developing a competitive advantage for successful exporting because SMEs are unlikely to be given free access to such resources in another country (Xinming and Yingqi, 2013; Freeman et al., 2012; Song et al., 2013). Different conditions in the country of origin, therefore, create their trade and location advantages (Zhang, 2016). Rugman (2010) sees CSAs as a foundation for SMEs internationalization. Locational advantages are pivotal to the success of SMEs. This is because their absence will have a negative impact on their growth and profitability (Freeman and Styles, 2014). Regarding providing network infrastructures, locational advantages will lead to improvements in export performance (Xinming and Yingqi, 2013). The positive effect of CSA on export performance is also supported by Chai et al., (2014); Song et al., (2013); Freeman and Styles (2014) and Rugman (2010). Thus, the following hypothesis is formulated:

H1: Government policy will have a positive and significant effect on country-specific advantage

While GPEP creates an enabling business environment, it also creates firm's specific advantages. A common factor limiting SMEs to exporting and of which GPEP can provide an answer is finance. Export finance is taken to mean self-financing, money market financing, development bank financing and capital market financing (Onaolapo and Odayemi, 2011). Mah (2012) include tax and financial incentives, the establishment of free trade zones and the supporting organizations to provide SMEs with excess cash for exporting. Thus, the following hypothesis is formulated:

H2: Government policy will have a positive and significant effect on export financing

GPEP also influences export marketing. Shamsuddoha et al., (2009) see export marketing as the ability of the firms to respond to marketing forces to achieve its objectives. Nazar and Saleem (2009) looks at it in relation to the product mix. This research contextualizes export marketing to include marketing information relating to the quality of product exported, product mix, and understanding of documentation for exporting. GPEP are very instrumental in the provision of such export marketing information to SMEs. This includes aspects such as the promotion of national trade fairs and exhibitions, networking opportunities with export associations (Gençtürk and Kotabe, 2001) how to export 
handbooks, export counseling, participation in foreign trade shows, preparation for market analysis among others (Francis and Collins-Dodd, 2004). Thus, the following hypothesis is formulated:

H3: Government policy will have a positive and significant effect on export marketing information

GPEP also helps SMEs develops their management capabilities. Management capability according to Zou and Stan (1998) involves a combination of management's international orientation, export commitment; perceived export advantages and barriers of exporting. This research extends it to include general know-how and knowledge about the business. These capabilities can be provided by the government through advisory services and training, financial aids to new start-ups, promotion of national trade fairs and exhibitions (Gençtürk and Kotabe, 2001; Francis and Collins-Dodd, 2004; Shamsuddoha et al., 2009). Seringhaus and Rosson, (2001) identified export promotion programs such as seminars for potential exporters, how to export handbooks, export counseling, participation in foreign trade shows, and preparation for market analysis. All of these policies/programs constitute external resources for the firms needed to help build management perception, improve their level of education about exporting and also increases their knowledge about exporting (Lages and Montgomery, 2005). Programs such as export seminars, overseas visits among others do not only help in propagating the benefits of exporting but also encourages management of firms who are sluggish in pursuing exporting to become more involved. Thus, the following hypothesis is formulated:

H4: Government policy will have positive and significant effects on management capabilities

\section{Determinants of Export Performance}

In this research, GPEP, and country specific advantages are considered external determinants while the firms export finance, export marketing information and management capabilities are considered internal since they have to originate from within the SMEs. Therefore the role of government policy on export performance needs to be understood regarding its effects on the internal and external factors that determine export performance. These determinants have been hypothesized to have a positive and significant effect on export performance as discussed below. 
The effects of country-specific advantages on the export performance of SME Cocoa exporters is related to the effects of external environmental factors such as the structure and operations of the industry, domestic and foreign market characteristics (Lages, 2000). The business environment provides both threats and opportunities to which firms have to respond to achieve competitive advantage and these, in turn, depend on the resources at the disposal of the firm (Gençtürk and Kotabe, 2001). While the government has been the largest provider of external resources to firms in every economy, it has also helped in developing the awareness of opportunities massively through policies like trade shows, workshops, and newsletters among others (Gençtürk and Kotabe, 2001). Government policy has also enabled SMEs to network. This networking has improved trust and commitment within trading partners and also reduced costs which are all very critical aspects in determining performance (Styles et al., 2008). SMEs are expected to benefit from these country advantages in pursuing exporting and improving their export performance. Thus, the following hypothesis is formulated:

H5: Country-specific advantages will have a positive and significant effect on the export performance of SME Cocoa exporters

Export finance is defined as a vector of self-financing, money market financing, development bank financing and capital market financing (Onaolapo and Odeyemi, 2011). SMEs are suffering from financial liabilities and providing them with finance or access to finance can help improve on their business activities and hence performance (Harash et al., 2014). Access to these sources of financing provides SMEs with credit, loans or investible capital to create a new venture and to finance day-to-day operations. SME Cocoa exporters use the export financing for promoting exports and export-related transactions. With regards to GPEP, the focus here is on the extent to which SMEs gain access to loans at favorable terms and how effective funds are used across the SMEs functional activities. A major challenge facing SMEs in the Cocoa industry in Africa is the risks associated with all four sources of finance, implying that export performance depends not only on access to financing but also on how the funds are used to create value by SMEs (Onaolapo and Odeyemi, 2011). Thus, the following hypothesis is formulated:

H6: Export finance has a positive and significant effect on the performance of SME Cocoa exporters 
Export marketing is another important determinant of export performance as it deals with marketing that extends across borders (Manfred and Mariella, 2016). Export marketing has to deal with the knowledge of consumers taste, product mix, and knowledge. Export marketing, therefore, deals with marketing information that enables SMEs to make the right decision for exporting. Understanding export marketing is important because the business environment is driven by competition (Qun and Sousa, 2015). Firms must also adapt their marketing mix strategy to be able to compete (Sraha, 2015). With export marketing capabilities, firms can adapt to changing demands (Jieke et al., 2016). Therefore identifying the right market for export, the right price and quality of the product are essential for improving export performance which also brings the issue of strategy into perspective (Cavusgil and Zou, 1994). Having knowledge about customers taste, product quality, and price and even how to export is a massive resource that helps overcome barriers to export and thereby improve export performance (Mário et al., 2016). Possessing export marketing capabilities can lead to firms pursuing low-cost strategies which eventually leads to improved performance. Thus, the following hypothesis is formulated:

H7: Export marketing will have a positive and significant effect on the performance of SME Cocoa exporters

Management capabilities are conceptualised as a vector of management perception, knowledge, and skills required to develop and implement an articulate export strategy (Lages, 2000). These factors explain the willingness, ability, and commitment of firms to engage in exporting (export involvement) by devoting sufficient managerial, human and financial resources (Aaby and Slater, 1989) and where possible taking advantage of government's export promotion programs (Shamsuddoha and Ali, 2006; Shamsuddoha et al., 2009). The export market is competitive, and SMEs have to adapt (Griffith et al., 2016). However, adapting requires SMEs to have the right capabilities (Mário et al., 2016). Based on the review of Jieke et al., (2016), management capabilities as determinants of export performance have a positive effect on export performance because they provide management with the knowledge to deal with export documentations and make sales from well-performing markets. Acquisition of capabilities should be spontaneous and sustainable due to changing demands (Souchon et al., 2016). Some 
managers, therefore, perceive high risk in export markets because they lack the capabilities needed to make inform decisions (Mário et al., 2016). Lack of management capabilities limit the chances of the firm to extend it marketing operations (Shamsuddoha et al., 2009). However, managers who possess these capabilities tern to develop a favorable attitude towards exporting by taking a proactive and rational market entry decision. These capabilities have a positive impact on export performance by enabling them to network, to better understand the business context and make the right decisions and become competitive (Nazar and Saleem, 2011; Ibeh, 2003). Extant literature also revealed that management capabilities represents resources in the context of the RBV and have a positive effect on export performance (Souchon et al., 2016; Jieke et al., 2016). Thus, the following hypothesis is formulated:

H8: Management capabilities will have a positive and significant effect on the performance of SME Cocoa exporters

Finally, the direct effect of GPEP on export performance has received many reviews from many researchers such as Gençtürk and Kotabe (2001); Wilkinson and Brouthers (2006); Francis and CollinsDodd (2004); Sraha (2015), where greater use of GPEP leads to increase performance. These studies also found positive results between the use of GPEP and export performance though in a different context. Geldres-Weiss and Carrasco-Roa (2016) argued that even though firms using GPEP had an increase in export performance, non-users also had performance increase in exporting and this makes it hard to believe how GPEP increases export performance. However, a review by Jieke et al., 2016) shows GPEP as a determinant of export performance to be having a positive effect on improving export performance. This view has also been supported by Mário et al., (2016). This is because GPEP helps SMEs to leverage their marketing capabilities into a competitive advantage (Tan et al., 2015). Moreover, $\mathrm{Ng}$ et al., (2016) note that GPEP improves export performance because it enables the firm to improve service and product quality. These vectors of government actions can influence export performance in different ways. It may be as a result of direct subsidies, financial assistance, tax holidays, specific training to and information that enhance export competence. Thus, the following hypothesis is formulated: 
H9: The usage of government policies for export promotion positively influences the export performance of SME Cocoa exporters.

Based on the above, the RBV of the firms seems to be the best concept for the study as GPEP act as an external resource to SMEs by enabling them overcome barriers to exporting. Despite GPEP having the influence on many other firms' determinants, the above framework shows it influences performance direct and indirectly through country and firms specific advantages. It was also important to measure performance using both financial and nonfinancial measures to provide a balance of overall performance. The next section will focus on the research method.

\section{Research Method}

\section{Research Context: SME Cocoa Exporters Cameroon}

Over the past two decades, the Cocoa Sector in Cameroon has witnessed remarkable evolution necessitating a re-examination of its place in international business research. The historical evolution of Cocoa exporting in Cameroon (Coulter and Abena, 2010) reveals its contextual relevance for this research. In the 1970s and 1980s, Cocoa was commercialized by a state monopoly corporation, namely, the National Board for the Marketing of Basic Commodities (ONCPB) in partnership with the Cocoa Development Society (SODECAO) and the Regional Unions of Agricultural Cooperatives (UCA). These unions had divisional, sub-divisional and village representatives to coordinate the Cocoa producing and transportation activities of local farmers, including the provision of finance for operations, supply of inputs, quality control, and bringing producers together and acting as a monopoly in the purchase of the produce for onward transportation to ports. The ONCPB acted as a standardization fund or bank, a unique monopoly exporter and the main structure in the commercialisation process. However, the economic crisis of the late 1980s led many Cocoa producing African countries to subscribe to the IMF/World Bank's proposed structural adjustment programs (SAPs).

The SAPs introduced privatization and liberalization and ensured that the corporative movement had to be replaced by a competitive market-based alternative. This alternative saw the emergence of licensed buying agents (LBA), unlicensed buying agents (ULBA) and common initiative groups (CIGs) who 
started buying from farmers to resell to the ONCPB. Moreover, the falling prices for Cocoa around 1989 made it difficult for the ONCPB to support producers' price which led to the liberalization of the sector in the 1990s. In 1991, the ONCPB was closed. The National Cocoa and Coffee Board (ONCC) and the Inter-professional Council for Cocoa and Coffee (CICC) were the two institutions created to manage and organize the subsector (Gbetnkom and Sunday, 2002). Thus privatization and liberalization saw the growth of LBA, ULBA, and CIGs who are now categorized as SME Cocoa exporters who export directly and indirectly to foreign markets (Boansi, 2003; Coulter and Abena, 2010). This categorization that is consistent with international comparisons (UNCTAD, 2005; 2010). The growing involvement of SMEs in the commercialisation of Cocoa via exporting has not yet received attention in international business research.

\section{Questionnaire, Sampling and data collection procedures}

The questionnaire was developed through stages between January and March 2015. First, literature on export performance and GPEP was reviewed to formulate the questions. Second, the questionnaire was sent to four academic researchers (two from Cameroon and two from the UK) for content validity. The third stage involved a pilot study with twelve SME Cocoa exporter's managers to assess the ease of them understanding and answering the questionnaire and if they could accept a mail survey. It was also to determine the willingness and ability of respondents to complete, detect errors in its design or questions and also to make a recommendation where ever possible. The pilot questionnaire was emailed to two Cameroon-based University graduates to distribute to respective managers to complete at their convenience. The research assistants then scanned the completed questionnaires and emailed to the author. It was clear from the pilot study that self-administered questionnaires was the best option due to respondents' busy schedule. All the recommendations were put in the final questionnaire that was selfadministered by the author and the research assistants using snowball sampling technique.

Probability sampling has been used to determine the sample frame for most studies in the developed economies due to the existence of a well-established and regularly updated databases (Jeike et al., 2016). The lack of an established and updated database in Cameroon as reported by Ngoasong (2007) has made purposive sampling the only alternative to determine the sample size. This purposive sampling was used 
to select SMEs that had been in business for at least three years, had been able to realize the effects of GPEP and where located within the South West and Centre Regions responsible for $50 \%$ and $30 \%$ of total Cocoa produced and exported in Cameroon (Ngoon and Forgha, 2013).

Snowball technique was facilitated due to the author's previous experiences as a Cocoa farmer and Cocoa buying sales agent before enrolling into $\mathrm{PhD}$ studies. The lack of modern technologies to automate the business process in Cameroon Ngoasong, 2007) is even worse in the Cocoa Sector where many SMEs do not even have a computer. This means mail survey was an impossibility. Questionnaires were administered in April 2015 to selected managers of SMEs that had business for at least three years in business (since some SMEs open and liquidate the next year) to be able to evaluate the effectiveness of these policies. Out of the 120 questionnaires that were self-administered, 101 were deemed usable and retained, while 19 were discarded due to missing answers or incomplete scores. This gave a response rate of $84 \%$ which is a reasonable response rate when compared with Francis and Collins-Dodd (2004); Wilkinson and Brouthers (2006); Freeman and Styles (2014).

\section{Characteristics of Sampled SME Cocoa Exporters}

After the questionnaires had been coded and entered into SPSS statistical software, descriptive statistics was used to present the characteristics of the sampled SMEs. The characteristics were based on ownership status, the number of employees, the size of capital, the number of years in business and the level of education of the managers. The analysis shows that $58.4 \%$ of the SMEs were privately owned and $41.6 \%$ were partnerships. Based on the number of employees, it was noticed that $39.6 \%$ had between $5-10$ and $10-15$ employees respectively while $5 \%$ had less than five employees. While a majority (65.3) of the SMEs had start-up capital between 0 -25 Million CFA, 49.5\% have been in business for 8 -13 years and the majority of the owner-managers $(67.3 \%)$ only had a secondary or vocational education with just $12.9 \%$ possessing university degree. Details about these characteristics can be found in Table 1. 


\section{Measurement of Variables}

Export performance, country, and firms' specific advantages were all latent variables. The only nonlatent variable was government policies for export promotion. The following paragraphs describe how the latent and non-latent variables have been measured.

All four latent variables were measured using multi-scales which are consistent with Seringhaus (2013); Shamsuddoha et al. (2009); Francis and Collins-Dodd (2004); Marandu (1996); Gençtürk and Kotabe (2001). These latent variables consist of export performance, country specific advantages, and firm specific advantages. Respondents were asked a series of questions for them to respond with their level of agreement or disagreement $(1=$ strongly agreed and $7=$ strongly disagreed $)$. Export performance was also measured following Shamsuddoha et al. (2009). Measures of export performance were chosen to reflect the context of the study. Respondents were asked to indicate their expectations on profit, increase in the scale of business, the establishment of direct contacts with customers, return on investments over the past three years $(1=$ below expectations and $7=$ above expectations $)$.

Seven government policies for export promotion were taken into consideration for this study. Respondents were asked if they are aware or not aware and if they have used such policies and to rate their associated benefits derived from using the policies. The protocol was as follows for each of the policies; $(\mathrm{A}=$ Not aware of government policies, $\mathrm{B}=$ Aware but have never benefited from government policies and $\mathrm{C}=$ Aware and have benefited from government policies). Respondents who ticked option "C", where then asked to rate their benefit on a seven-point Likert scale (with $1=$ Not at all benefit, $2=$ Not very much benefit, $3=$ A little benefit, $4=$ Somehow beneficial, $5=$ Benefit, $6=$ Considerable beneficial and 7= Very much beneficial). Respondents who ticked options "A" and "B" were also asked to give reasons why they are not aware of the existence of government policies for export promotion or why despite being aware, have never used or benefitted from such policies.

\section{Data analysis}


The indirect effects of GPEP on export performance were captured through country and firms specific advantages which have been conceptualized as latent variables in this research. The loadings of respective items on each latent variable are important in the understanding of the relationship. The direct and indirect effects also need to be captured in the best and robust possible way. On-like multiple regression, SEM was used because a single analysis was able to uncover the direct and indirect effects rather than running a series of multiple regression analysis (Yong and Pearce, 2013; Tabachnick and Fidell, 2007). A seven-point scale was used because validity increases when scales are lower than 5 and greater than eight (Tabachnick and Fidell, 2007). Moreover, common method bias (CMB) can cause problems in the result. Despite the many ways in dealing with CMB (Fuller et al., 2016), this research has used a seven-point Likert scale to prevent respondents recalling responses from previous items when responding to others. Moreover, Harman's single factor score has also been used to prevent CMB (Fuller et al., 2016). This was achieved by restricting items from cross loading using Varimax rotation.

Exploratory Factor Analysis (EFA) was used as a purification process because of its power of minimizing or reducing the data set to clearly defined sets with common variance (Yong and Pearce, 2013; Tabachnick and Fidell, 2007). The EFA was performed to identify any poorly performing items. Many items with low factor loadings or those that loaded on more than one factor were excluded. However, the conceptual definitions of the excluded items were taken into account to make sure they did not affect the factors predictability.

Factors were chosen by evaluating the Kaiser-Meyer-Olkin Measure (KMO) and Bartlett's Test of Sphericity, eigenvalue $\geq 1$, analyse the value of Cronbach's alpha for respective factors, the amount of variance explained and the number of variables loaded on each factor (Yong and Pearce, 2013; Tabachnick and Fidell, 2007). After the purification stage in which factors were selected for further investigation, a confirmatory factor analysis (CFA) was performed on the selected factors. This is because CFA is a strong tool used to identify model fit (Jackson et al., 2009). The model fit indices used have met the minimum threshold stipulated by Schumacker and Lomax (1996) such as (GFI = 0:968, $\mathrm{IFI}=0: 968, \mathrm{NFI}=0: 956, \mathrm{TLI}=0: 903$, and CFI $=0: 968$ ). This implies the data was a good fit for the analysis. The last stage was the path diagram which was used to obtain the direct and indirect effects 
with their respective level of significance. Table 2 below gives the result of the EFA and CFA for respective variables.

Table 2: Result of the EFA and CFA.

\section{Findings}

The objectives of this research were to explore the RBV and SEM techniques to develop nine hypothesis and thereby to uncover the effectiveness (direct and indirect effect) of GPEP on the export performance of SME Cocoa exporters in Cameroon. This framework was built on two important questions; 1) given the growing involvement of local SMEs in the export of Cocoa in African countries, how can the role of GPEP on the export performance of SME Cocoa exporters be best understood? 2) What are the direct and indirect effects of GPEP on the export performance of SME Cocoa exporters in Cameroon?

The 101 questionnaires retained for this research was filled by managers of SME within the Cocoa sector in the South West and Centre Region of Cameroon. Responding SMEs where those that have been in business for at least three years to be able to have experienced the effects of these policies on their business activities. All latent variables had an acceptable reliability based on Cronbach's alpha and a good model fit index as shown in Table 1.The descriptive statistics relating to the characteristics of respective SMEs have already been elaborated in Table 1 above. Moreover, Table 3 below presents the result of the SEM. Based on Table 3, GPEP was shown to be having both direct and indirect effect on export performance through the provision of country and firms specific advantages. The results are presented in the following sections, focusing on the direct and indirect effects of GPEP on export performance of SME Cocoa exporters.

\section{Table 3. Analytical Result of Structural Equation Model}

\section{The direct effect of government policies on export promotion on export performance.}

GPEP has direct and positive effects on export performance of 0.16 represented by H9 (table 3 ). This, suggest that use of GPEP by SME Cocoa exporters will improve their export performance. However, this direct effect is insignificant at 0.05 level of significance. Nevertheless, the relationship between 
GPEP and export performance have received mixed findings from the extant literature. Sraha (2015) reported GPEP to be having a significant effect on export performance. This positive and significant relationship has also been reported by Jindal and Gakhar (2013); Wilkinson and Brouthers (2006); Lages and Montgomery (2005). Francis and Collins-Dodd (2014) concluded that even though GPEP is expected to have a positive effect on export performance, a non-significant relationship may be attributed to the number of GPEP used by firms. Relating this to Cameroon as a less developed country Lages and Montgomery (2005) argued that corrupt governments are restricting GPEP to friends, family member and those loyal to the regime in power. This was evident from the author's field observation in which informal discussions with the participants raised the issue of corruption as a barrier for benefiting from GPEP. This makes it tough for some SME Cocoa exporters to benefit from many of such policies and therefore reduces its effect on their performance. In acknowledging a similarly positive relationship, Gençtürk and Kotabe (2001) argued that its significance will be based on the level of export involvement. Again, many SME Cocoa exporters are resource deficient and pursue exporting indirectly through multinationals. This, therefore, limits their level of export involvement and hence the benefit from GPEP.

The indirect effect of government policies on export promotion on export performance

The indirect relationship of GPEP on export performance captured through the provision of country and firms specific advantages is represented by hypothesis H1- H8. Looking at Table 3, it is evident that both the direct and indirect effect of GPEP on export performance are positive. This implies that the total effect is also positive and therefore the granting of subsidies, participating in trade shows, trade fairs, and trade missions, creation of export processing zones, signing of trade agreements, and provision of market information, making it possible for SMEs to obtain loans from commercial banks, making it easier to create a business and understanding the laws of business creation, were seen to be influential determinants of export performance. This direct and indirect effects may be considered in figure 2 below. 


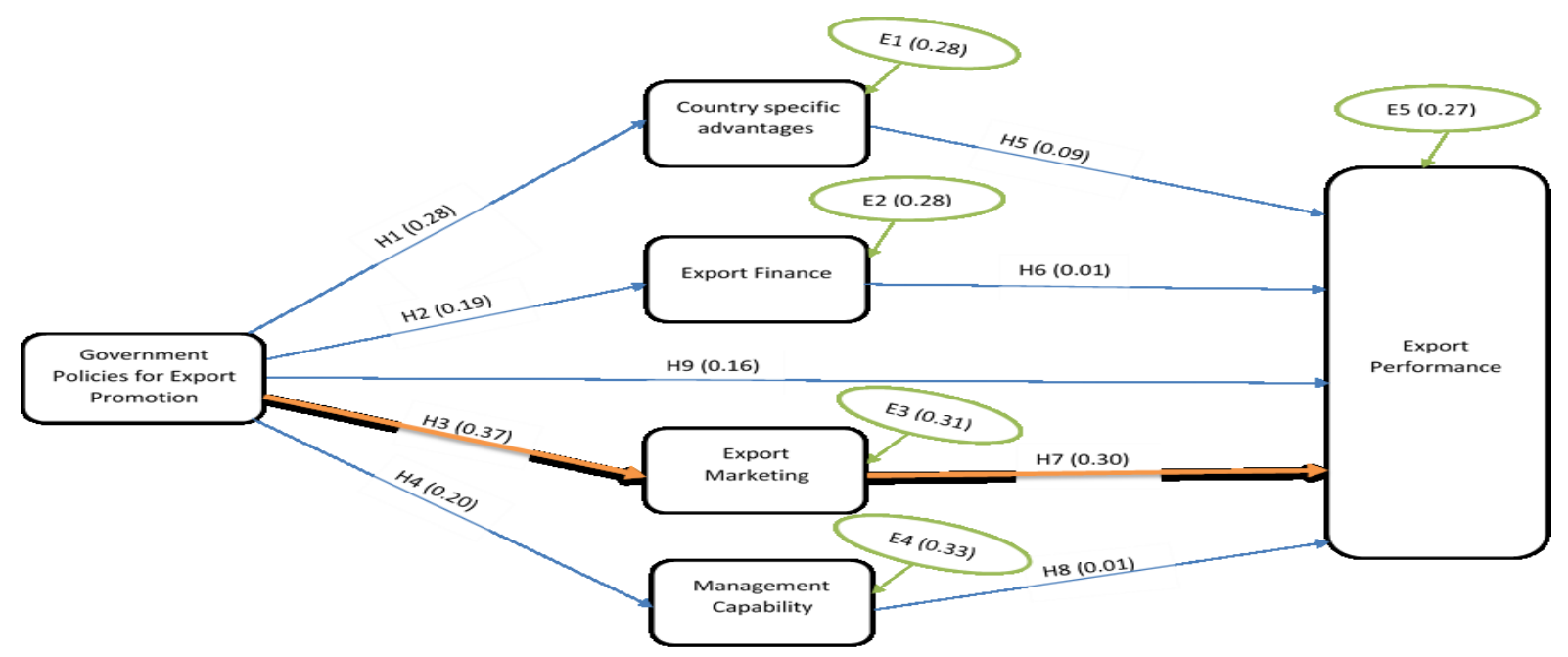

Despite that fact that the indirect effects through country and firms specific advantages were positive, not all were significant at .05 level of confidence. The path from GPEP to export performance through Country specific advantages Fig 2 above is represented by hypotheses H1 and H5 and reveals a positive effect on the export performance of SME Cocoa exporters. However, while H1 was positive and significant, H5 was also positive but not significant as seen in Table 3 . This insignificant effect of country-specific advantages whose items are represented in Table 2 raises serious concern about the accessibility of CSA by SME Cocoa exporter in Cameroon. While Chai et al., (2014); Song et al., (2013); Freeman and Styles (2014) and Rugman (2010) as potential source for the very beginning of developing competitive advantage for successful exporting, Zhang (2016) raises the issue of the associated cost of benefiting from such advantages. This associated cost can, therefore, be used to justify the nonsignificant relationship between for H5. Relating this results to Cameroon, accessibility has always of country advantages is a major issue. To benefit from such advantages may require being loyal to the regime on power, having friends in government or given bribe as mentioned by Lages and Montgomery (2005). Some managers of SME, therefore, will not want to change their political inclination and therefore limit their access to these advantages which in effects reduces the full impact on their performance.

Moreover, the other indirect effects were captured through the path of $\mathrm{H} 2-\mathrm{H} 6, \mathrm{H} 3-\mathrm{H} 7, \mathrm{H} 4-\mathrm{H} 8$. Hypotheses $\mathrm{H} 2, \mathrm{H} 3$, and $\mathrm{H} 4$ represent that path from GPEP to firms specific advantages (export finance, 
marketing information, and management capabilities). Table 3 also show that these hypotheses were positive and significant. Moreover, Hypotheses H6 and H8 were positive but not significant while hypothesis $\mathrm{H} 7$ was positive and significant as shown in Table 3. This means that the only positive and significant indirect relationship was through the path $\mathrm{H} 3-\mathrm{H} 7$ as indicated by the colored line in figure 2 above. GPEP were seen to be significant in providing export market information such as the knowledge about the product quality, knowledge about the marketing mix, understanding of the documentation formalities in exporting, and the knowledge of trade barriers. This is because many SME Cocoa exporters have lost millions in the export market as a result of poor quality of Cocoa being exported. This hypothesis was also supported by (Zou et al., 2003) who also saw export marketing regarding pricing, distribution, communication, and product quality to be having a positive effect on export performance for Chinese exporters. Al-Aali et al., (2013) found that having the right product, the right promotion and the right distribution of their products had improved export performance.

Nevertheless, the non-significant indirect effect through the other firm's specific advantages (H6 and H8) was due to some factors. Even though the government provides finance for exporting in various ways, many SME Cocoa exporters prefer not to apply for such finance since it will expose their business to the government and potentially leads to tax increases. Moreover, a major source of finance for SME Cocoa exporters comes from large multinationals or large domestics Cocoa exporters. These large exporters finance the SMEs because some of them export indirectly through them. Some of the SME Cocoa exporters even buy Cocoa from farmers using arrangements. They will then pay the farmer after they have made their sales. In such a situation, they do not need much finance from the government.

GPEP also creates firm-specific advantages. However, the positive but non-significant relationships were not only due to the low level of awareness and usage of GPEP but were also due to bad governance within government institutions (Lages and Montgomery, 2005). The low level of awareness was due to a lack of information about their existence and usefulness of GPEP to SME Cocoa exporters. It was also due to a poor system of communication as most of the information being circulated was in the French language with a total neglect of English language. Moreover, many SME Cocoa exporters who were aware of the existence of GPEP did not use it due to their political orientation. The government knows 
those in opposition and makes sure they are excluded from the beneficiaries of its subsidies. Attending export workshops that are expected to educate the exporters and develop their capabilities becomes very difficult especially for the Anglophones who do not speak and understand the French language which is the main language of instructions in many of such seminars.

\section{Discussion and Conclusion}

This research makes two important contributions to the literature on international marketing. First, by answering the research questions, it contributes to the recent debate in international marketing in a sector (Cocoa sector) that is unique to Cameroon. This uniqueness is because Cocoa exporting in Cameroon was under the monopoly of the government controlled marketing board from independence in the 1060s to the 1990s (Coulter and Abena, 2010). Privatisation in the early 1990s saw the growth of SME Cocoa exporters in Cameroon. Drawing from previous studies on GPEP, this research has provided evidence of the nature of these programs on the export performance of SME Cocoa exporters in Cameroon by looking at the direct and indirect effects. The research shows positive direct and indirect effects through country and firms specific advantages of GPEP on export performance of SME Cocoa exporters. However, the only positive and significant relationship were through export marketing information. Nevertheless, the positive effects show the impact GPEP may have on export performance as supported by Jindal and Gakhar (2013); Wilkinson and Brouthers (2006); Francis and Collins-Dodd (2004). This contribution also differs from previous studies by looking at a different context and sector which have been called for by Francis and Collind-Dodd (2004) and more work on African countries by Jeike et al., (2016).

Secondly, the research contributes by developing a model for analysing the effect of GPEP on export performance from a developing country perspective, which is complimentary to prominent models that have been applied to more developed countries (Leonidou et al., 2011; Jieke et al., 2016; Sousa et al., 2008). As depicted earlier in Fig. 2, the model shows how export performance is being influenced by GPEP either directly or indirectly. The model is different from previous models within international marketing (e.g., Francis and Collins-Dodd, 2004), in that it does not only look at the direct effect of GPEP on export performance but also the indirect effects. The model is also different in that it does not 
consider the effect of GPEP on export performance based on the number of programs used and level of export involvement as in Francis and Collins-Dodd (2004) but based on the weighted average of GPEP derived by some programs used and associated benefits. The inclusion of country advantages in the model to empirically examine its effect on export performance is another distinguishing factor that has been advocated by Freeman and Styles (2014); Zhang (2016).

The findings of this research have both practical and policy implications for improving the performance of SME Cocoa exporters through government policies. The research provides the role of GPEP in helping SME Cocoa exporters to develop capabilities for successful exporting, and that also increases their export performance. The analysis revealed that most managers of SMEs are aware but do not engage the government authorities to seek ways of benefiting from policy initiatives, such as export promotion programs. Thus, one way forward is for managers of such SMEs to seek assistance from programs by making concerted efforts to contact the relevant government agencies. SMEs need to form a committee which makes recommendations to the government to either update some programs, provide more or less of some programs, providing new programs, or even eliminating programs not needed. Also, managers must, therefore, have a clear strategy for exporting when seeking GPEP to help them achieve this objective. The positive relationship also informs the government in two ways. First, to set up a committee responsible for creating the awareness of GPEP by ensuring SMEs have full. The government, therefore, has to disseminate information using every method possible to reach respective SMEs such as TV programs, radio announcements, and newspapers among others in both English and French. Secondly, the government needs to train SMEs on how to get the best out of existing policies such as sustaining contacts obtained during trade shows.

\section{Limitation and direction of future research}

This research analysed the direct and indirect effects through country and firms specific advantages of GPEP on export performance. Therefore although the model developed in this article can be applied to another developing country context, care must be taken when applying the model to other Cocoaproducing countries because the content and level of accessibility of GPEP and country advantages may vary across countries. Firms may also be at different stages of the internationalisation process, and their 
abilities to harness the benefits of GPEP may also differ (Francis and Collins-Dodd, 2004). These are contingencies that need to be taken into consideration when applying the model in a different context. However, there are other determinants such as the size of the firms and age of the firms that may influence the direct and indirect effects of export performance of the firm either as a moderating or mediating variable and which can provide an avenue for further research. Also, the research involved a single country analysis due to differences in policies across borders. Nevertheless, its universal application can be verified by testing the model in another African context where such research is limited. The research also is quantitative and has focused on the firm's management. However, GPEP is designed by the government. A qualitative research that captures the views of the providers (government) and receivers (SME Cocoa exporters) of GPEP can provide greater depth in reconciling their effectiveness which has received mixed findings. Qualitative research based on in-depth interviews can help uncover context-specific and information-rich data of the nature of interactions between government agencies and private commercial firms (e.g., Kimbu and Ngoasong, 2016). Since GPEP have been calculated as an aggregate through the weighted mean, it is important to analyse them distinctively for the government and the firms to know which programs need improvement, termination or replacement.

\section{REFERENCEE}

Aaby, N. and Slater, S.F. (1989), "Management Influences on Export Performance: A Review of the Empirical Literature 1978-1988”, International Marketing Review, Vol. 6, No. 4

Ahmed, B. Y. (2008), "Export Financing in Nigeria: Challenges and Solution's". A Paper presented at the national conference on non-oil exports in Nigeria, organized by CIBN/NEXIM Bank Lagos.

Al-Aali, A. Lim, J., Khan, T. and Khurshid, M. (2013), "Marketing Capability and Export Performance: The Moderating Effect of Export Performance", South African Journal of Business Management, Vol. 44, No. 3, pp. 59-70

Bamou, E. Tankou, L.B. and Tchanou, J.P. (2006), “Trade and Investment Policy Reforms in Cameroon: Impact Assessment and Perspectives", Yaoundé, Cameroon: University Of Yaoundé Ii (April). 
Bamou, L.T. (2002), "Promoting Export Diversification in Cameroon: Toward Which Products."

Bello, P., (2009), "Internationalization of Cameroonian Small and Middle Enterprises (SMEs): Myth or Reality?", African Journal of Business Management, Vol. 3, No. 2, pp. 052-069

Boansi, D. (2013), "Competitiveness and determinants of Cocoa exports from Ghana," International Journal of Agricultural Policy and Research, Vol. 1, No. 19, pp. 236-254

Cavusgil, S. T., and Shaoming, Z. (1994), "Marketing strategy-performance relationship: An investigation of the empirical link in export market ventures," Journal of Marketing, Vol.58: 1-21.

Chai, Z.D., and Liu, H.J. (2014), “An Analysis of the Home Factors in Competitive Advantages of the Emerging Market's MNEs," Nanjing Journal of Social Sciences, vol. 8, pp. 24-31

Collier, P. (2002), "Primary Commodity Dependence and Africa's Future," World Bank, Washington $D C$.

Coulter, J. and Abena, P.E. (2010), "Study of Value Chain Finance for Coffee and Cocoa in Cameroon," Report to UNCTAD, United Nations.

Czinkota, M. and Ronkainen, I. (2012), “International Marketing. ” Cengage Learning.

Ebong, B. (2008), "Developments in the Financial and payments systems for export," a paper presented at the International Conference on non-oil exports in Nigeria organized by NEXIM and CIBN, August. Forgha, N, G and Sama, M. C, (2014), "The Effects of Export Diversification on Economic Growth in Cameroon," International Invention Journal of Arts and Social Sciences, Vol. 1, No. 3, pp. 54-69

Francis, J., and Collins-Dodd, C., (2004), "Impact of Export Promotion Programs on Firm Competencies, Strategies, and Performance: The Case of Canadian High-Technology SMEs," International Marketing Review, Vol. 21, No. 4/5, pp. 474-495

Freeman, J. and Styles, C. (2014), "Does location matter to export performance?", International Marketing Review, Vol. 31, No.2, pp.181-208 
Freeman, J. Styles, C and Lawley, M. (2012), "Does firm location make a difference to the export performance of SMEs?", International Marketing Review, Vol. 29. No. 1, pp.88-113

Fuller, C. M., Simmering, M. J., Atinc, G., Atinc, Y., and Babin, B. J. (2016), “Common methods variance detection in business research," Journal of Business Research, vol. 69, No. 8, pp. 3192-3198

Gbetnkom, D., and Khan, S.A. (2002), “Determinants of Agricultural Exports: The Case of Cameroon,” African Economic Research Consortium.

Geldres-Weiss, V. V. and Carrasco-Roa, J. A. (2016), "Impact evaluation of national export promotion programs on export firms using contrast groups," International Journal of Export Marketing, vol. 1, No. 1, pp. 77-95

Gençtürk, E.F., and Kotabe, M. (2001), "The Effect of Export Assistance Program Usage on Export Performance: A Contingency Explanation,” Journal of International Marketing, Vol. 9, No. 2, pp. 5172

Griffith, D. A., Lee, H. S., Yeo, C. S., and Calantone R. (2014), "Marketing process adaptation: Antecedent factors and new product performance implications in export markets," International Marketing Review, Vol. 31, No.3, pp.308-334

Harash, E. Al-Timimi, S., and Alsaadi, J. (2014), “The Influence of Finance on Performance of Small and Medium Enterprises (SMEs),” Technology, Vol. 4, No. 3, pp. 161-167

Harif, M. A. A. M., Hoe, C. H., and Ahmed, M. I. (2013), "The Financial and Non-Financial Performance Indicators of Paddy Farmers' Organizations in Kedah," World Review of Business Research, Vol. 3. No. 1. Pp. 80-102

Ibeh, K.I.N. (2003), “On the internal drivers of export performance among Nigerian firms: Empirical findings and implications," Management Decision, Vol. 41, No. 3, pp. 217-225

International Cocoa and Coffee Organisation (2012), Annual Report 2013

Jieke. C, Carlos. M.P. S., and Xinming H. (2016) "The determinants of export performance: a review of the literature 2006-2014", International Marketing Review, Vol. 33, No. 5, pp.626-670 
Jindal, G., and Gakhar, K. (2013), “Export Promotion Programs and Exporters Performance, Strategies and Competencies: A Review," International Journal of Research in Management, Science, and Technology, Vol. 3, No. 4, pp. 117-175

Joanne F. and Chris S. (2014), "Does location matter to export performance?", International Marketing Review, Vol. 31, No. 2, pp.181-208

Julian, C.C. and Ahmed, Z.U. (2005), “The Impact of Barriers to Export on Export Marketing Performance," Journal of Global Marketing, Vol. 19, No. 1, pp. 71-94

Julian, C.C., and Yunus Ali, M. (2009), "Incentives to Export for Australian Export Market Ventures," Journal of Small Business and Enterprise Development, Vol. 16, No. 3, pp. 418-431

Khazragui, H. (2011), “Export Promotion of Small and Medium Sized Enterprises in Developing Countries: The Perceived Usefulness of International Trade Points by SMEs in Egypt.

Kimbu, A. N., and Ngoasong, M. Z. (2016), “Women as vectors of social entrepreneurship,” Annals of Tourism Research, pp 63-79.

Lages, L.F., and Montgomery, D.B. (2005), "The Relationship between Export Assistance and Performance Improvement in Portuguese Export Ventures: An Empirical Test of the Mediating Role of Pricing Strategy Adaptation,” European Journal of Marketing, Vol. 39, No. 7/8, pp. 755-784.

Larimo, J. (2006), "Different types of exporting SMEs: Similarities and differences in export performance," Advances in International Marketing, Vol. 7, No. 17, pp. 17-62

Leonidou, L. C (1995), "Export barriers: non-exporters' perceptions," International Marketing Review, Vol. 12, No. 1, pp.4-25

Leonidou, L. C, Katsikeas, C. S, Palihawadana, D and Spyropoulou, S. (2007), “An analytical review of the factors stimulating smaller firms to export: Implications for policy-makers," International Marketing Review, Vol. 24, No. 6, pp.735-770 
Leonidou, L. C. (2004), “An Analysis of the Barriers Hindering Small Business Export Development," Journal of Small Business Management, Vol. 42, No. 3, pp. 279-302

Leonidou, L.C. and Katsikeas, C.S. (1996), “The Export Development Process: An Integrative Review of Empirical Models,” Journal of International Business Studies, pp. 517-551

Mah, J. S. (2010), "Export promotion policies, export composition and economic development of Korea.” Journal of Economic Issues, Vol. 4, No. 4, pp. 877-894

Manfred, F., and Mariella, K. (2016), "Antecedents and consequences of firm's export marketing strategy: An empirical study of Austrian SMEs (a contingency perspective)," Management Research Review, Vol. 39. No. 3, pp.329-355

Marandu, E.E. (1996), "Impact of Export Promotion on Export Performance: A Tanzanian Study," Journal of Global Marketing, vol. 9, No. 1-2, pp. 9-40

Mário Henrique Ogasavara, Dirk Michael Boehe, Luciano Barin Cruz, (2016), "Experience, resources, and export market performance: The pivotal role of international business network ties," International Marketing Review, Vol. 33, N0. 6, pp.867-893

Memfih, N.M. (2008), “A Balance Sheet of Economic Development Experience since Independence,” Civil Society and the Search for Development Alternatives in Cameroon, pp. 35

Molua, E.L. (2008), “Turning up the Heat on African Agriculture: The Impact of Climate Change on Cameroon's Agriculture," African Journal of Agricultural and Resource Economics, vol. 2, No. 1, pp. $45-64$

Tore, Mysen. (2013),"Towards a framework for controls as determinants of export performance," European Business Review, Vol. 25, No. 3, pp. 224-242

Nazar S. M. and Saleem N. H. (2009), "Firm-Level Determinants of Export Performance," International Business and Economics Research, Vol. 8, No. 2, pp. 105-112 
Ng, K., Abd, R. A., and Chua, P. S. (2016)," Export Promotion, Sales, and Profits: A Structural Equation Modelling," Journal of Southeast Asian Research, Vol. 2016 (2016), Article ID 309540, DOI: $10.5171 / 2016.309540$

Ngoasong, M.Z. (2007), “Does Innovation Matter for Economic Development? An Empirical Study of Small and Medium-Sized Enterprises in the City of Kumba-Cameroon", Studia Universitatis BabesBolyai: Negotia, vol. 52, No. 1, pp. 91-110.

Ngoong, J., and Forgha, N. (2013), “An Analysis of the Socio-Economic Determinants of Cocoa Production in Meme Division of Cameroon," Greener Journal of Business and Management Studies, Vol. 3, No. 6, pp. 298-308.

Njinyah, S. and Ngoasong, M. (2014), “A conceptualization to investigate the direct and indirect impacts of government policy on the performance of SME Cocoa exporter in African economies," In: Academy of International Business Annual Meeting, 23-26 June 2014, Vancouver, Canada.

OECD (1984), “Competition and Trade Policies: Their Interaction” Paris: OECD Publishing

Olejnik, E., and Swoboda, B. (2012), "SMEs' internationalization patterns: descriptive, dynamics, and determinants," International Marketing Review, Vol. 29, No. 5, pp.466-495

Onaolapo, A. and Odeyemi, J. (2011), "Relationship between Export Finance and Cocoa Export Performance in Intermediate Cocoa Processing Firms in Southwestern Zone of Nigeria," International Journal of Economic Development Research and Investment, Vol. 2, No. 2, pp.112-121

Pinho, J. C. (2007), "The impact of ownership: Location-specific advantages and managerial characteristics on SME foreign entry mode choices," International Marketing Review, Vol. 24, No. 6, pp. $715-734$

Qun Tan and Carlos M.P. Sousa (2015),"Leveraging marketing capabilities into competitive advantageand export performance", International Marketing Review, Vol. 32, No.1, pp. 78 - 102 
Rugman, A.M. (2010), "Reconciling Internalization Theory and the Eclectic Paradigm," Multinational Business Review, Vol. 18, No. 2, pp. 1-12

Seringhaus, F.R. (2013), “The Impact of Government Export Marketing Assistance," International Marketing Review.

Seringhaus, F.R., and Rosson, P.J. (2001), “Firm Experience and International Trade Fairs,” Journal of Marketing Management, Vol. 17, No. 7-8, pp. 877-901

Shamsuddoha, A. and Yunus Ali, M., (2006), "Mediated Effects of Export Promotion Programs on Firm Export Performance," Asia Pacific Journal of Marketing and Logistics, Vol. 18, No. 2, pp. 93-110

Shamsuddoha, A., Ali, M.Y. and Ndubisi, N.O. (2009), "A Conceptualisation of Direct and Indirect Impact of Export Promotion Programs on Export Performance of SMEs and Entrepreneurial Ventures," International Journal of Entrepreneurship, Vol. 13, No.1, pp. 87

Shoham, A., (1998). Export Performance: A Conceptualization and Empirical Assessment. Journal of International Marketing, pp. 59-81.

Song, Z.N. and Yin, Z.M. (2013), "The Transfer from Country-Specific Advantages to Firm-Specific Advantages: Logic Paths and Realistic Barriers," International Economics and Trade Research, No. 6, pp. $25-35$

Souchon, A. L., Hughes, P., Farrell, A. M., Nemkova, E., and Oliveira, J. S. (2016), "Spontaneity and international marketing performance," International Marketing Review, Vol. 33, No.5, pp.671 - 690

Sousa, C., Martínez-López, F. J., and Coelho, F. (2008), “The determinants of export performance: A review of the research in the literature between 1998 and 2005,". International Journal of Management Reviews, vol.10, No.4, pp. 343-374

Sraha, G. (2015), "Public policy makers: Improving export promotion programs and entrepreneurial development in a lower emerging economy," African Journal of Economic and Management Studies, vol.6, No1, pp. 55-71 
Styles, C. Paul, G. P. and Farid, A. (2008), “A relational model of export performance,” Journal of International Business Studies, Vol. 39, No. 5, pp. 880-900

Tabachnick, B. and Fidell, L. (2007), "Multivariate Analysis of Variance and Covariance," Using Multivariate Statistics, Vol. 3, pp. 402-407

Truett, D.B. and Truett, L.J. (1994), "Government Policy and the Export Performance of the Mexican Automobile Industry," Growth and Change, Vol. 25, No. 3, pp. 301-324

UNCTAD, 2005; 2010

Wilkinson, T. and Brouthers, L.E. (2006), "Trade Promotion and SME Export Performance," International Business Review, vol. 15, No. 3, pp. 233-252.

Xiao, W., and Zhou, J.Z. (2014), “Chinese OFDI Location Preferences with Country-Specific Advantages: An Empirical Analysis Based on Firms' Investment Motivation and Capability," Journal of Zhejiang University (Humanities and Social Sciences), vol. 44, pp. 184-196

Xinming H. and Yingqi W. (2013), "Export market location decision and performance: The role of external networks and absorptive capacity," International Marketing Review, Vol. 30, N0. 6, pp.559 590

Yannopoulos, P. (2010), “Export Assistance Programs: Insights from Canadian SMEs," International Review of Business Research Papers, Vol. 6, No. 5, Pp. 36-51

Yong, A.G., and Pearce, S. (2013), “A beginner's Guide to Factor Analysis: Focusing on Exploratory Factor Analysis," Tutorials in Quantitative Methods for Psychology, vol. 9, No. 2, pp. 79-94

Zhang, H. R. (2016), "Literature Review on Country-Specific Advantage," Journal of Service Science and Management, vol. 9, pp. 111-118

Zou, S., and Stan, S. (1998), “The Determinants of Export Performance: A Review of the Empirical Literature between 1987 and 1997”, International Marketing Review, vol. 15, No. 5, pp. 333-356 
Zou, S., Fang, E. and Zhao, S. (2003), "The Effect of Export Marketing Capabilities on Export Performance: An Investigation of Chinese Exporters," Journal of International Marketing, vol. 11, No. 4, pp. $32-55$

Leonidou, L.C., D. Palihawadana, and M. Theodosiou (2011),“ National export promotion programs as drivers of organizational resources and capabilities: Effects on strategy, competitive advantage, and performance," Journal of International Marketing, 19(2), 1-29 